

\section{Inner and deeper: Motifs of fiction in Werner Herzog's films}

\section{Chantal Poch}

\section{Introduction}

Asking ourselves about the nature of fiction in film brings up to the question whether this fiction acts as an opposite of truth or, indeed, as truth itself. Bavarian director Werner Herzog has built an entire oeuvre regarding this problem: from the blurry lines between his fictional movies and documentaries to the recurrent inclusion of false quotes and events on his scripts, all of his films seem to add something to the same direction: the confusion of fact and fiction. The emphasis on this confusion has been predominant in the studies about his concepts of fiction and truth, leading to the same result again and again - for Herzog, poetic truth is more important than factual truth. But, how can we deepen into this conclusion? It seems to me that a work so hardly compromised with this play of categories has something more to say about this relation. In this paper I will try to open an alternative path to comprehend his concepts of fiction and truth that merges more adequately with his philosophy of filmmaking. I will argue that in order to understand Herzog's concepts of fiction and ecstatic truth and their relation it's not sufficient to focus on the side of function: we need to turn towards expression. 
Fiction studies have centred on reception for a while. In what allegedly is one of the most influential theories in the field, Walton (1990) defines fiction mainly for its purpose: to prompt imagination, to guide it, thus centring the meaning of fiction in the spectators' side. For Herzog, imagination is also important when it comes to fiction, but he has always shown a greater interest on the process of creation and expression than on the function of his images: his care is not for falling into a category or another, for accomplishing audience expectations or not, but for expressing or not an interior truth to them. Given this, an analysis that relies on the poetic content of his movies will be the best method to get us closer to what fiction means for the director. After all, we must not forget his statement "I am my films".

The main thesis of this article will be, then, that the concept of "fiction" in Herzog's work can be studied through the detection of visual and narrative motifs in his work. The identification of motifs is an especially useful methodology in the study of works produced in a long period of time by the same artist, and such is the case. The repetition of similar ideas over the years leads us to the main artistic preoccupations of the filmmaker - to return to the same motif is to ask the same question again (Balló 2000; Balló \& Bergala 2016).

This thesis has been broken down to four ideas around which the paper will structure: 1) that exploring what fiction means in Herzog's films from a point of view that focus on reception is not enough given the intricacy of the categories fiction and non-fiction in his work, 2) that the 
filmmaker's extra filmic concept of truth is parallel to the concept of fiction, and that in this association he is echoing a romantic tradition, 3) that the notion of an inner, deeper truth has an aesthetic and thematic translation into his films based on a poetics of the depth, 4) that the absence of faith in a factual truth has an aesthetic and thematic translation onto his films based on a poetics of the dream and the vision.

\section{The lies among the truth}

The first aim of this article is to prove that an analysis of Herzog's treatment of fiction that relies on separation from truth falls short on a work with such a tendency to blur the lines between the categories of fiction and non-fiction. We will do that by identifying the exact location and extent of these blurs, something that, given the popularity of this affirmation (see Weinrichter 2007; Casau 2014; Corrigan 2013), hasn't been scrutinized that much. What begins as a mere exercise of separating easily distinguishable pieces of fiction from truth will end up in a complex net of facts and inventions which makes it meaningless to try to comprehend what purpose fiction has in a specific film. 
The most popular and noticeable occasions in which Herzog mixes fiction with non-fiction are, of course, within his documentaries. By identifying a film as a documentary, the spectator expects the facts depicted on it as true, as in non-fictional. Herzog has transgressed this horizon of expectations by including his own inventions side to side with the real facts of his documentaries. The most known practice by the filmmaker in this regard is the constant play with the attribution of quotes, which we can trace back to Land des Schweigens und der Dunkelheit/Land of Silence and Darkness (1971, West Germany): the film ends with a quote by the filmmaker, "Wenn jetzt ein Weltkrieg ausbrechen würde, würde ich das nicht einmal bemerken" (If a worldwide war would break out now, I wouldn't even notice it) (1:20:36) which by being not accompanied by a name and by its situation in the film leads us to misattribute it to one of the characters that we have just seen. The beautiful text at the end of Die große Ekstase des Bildschnitzers Steiner / The Great Ecstasy of Woodcarver Steiner (1974, West Germany), a documentary about the ski-jumper Walter

Steiner, is also misleading in its origin, as it speaks of a Steiner in first person:

"Ich sollte eigentlich ganz allein auf der Welt sein, ich, Steiner, und sonst kein anderes lebendes Wesen. Keine Sonne, keine Kultur, ich nackt auf einem hohen Fels, kein Sturm, kein Schnee, keine Straßen, keine Banken, kein Geld, keine Zeit und kein Atem. Ich würde dann jedenfalls keine Angst mehr haben." (0:42:37:)

I should be all alone in the world, just me, Steiner, and no other living being. No sun, no culture; I, naked on a high rock, no storm, no snow, no streets, no banks, no money, no time and no breath. Then, finally, I would not be afraid anymore. 
Herzog, though, has explained that it was a text based on words by Robert Walser (Herzog \& Weigel 2010: 12; Cronin 2002: 97). Two more fake quotes: neither Pascal wrote the opening line of Lektionen in Finsternis/Lessons of Darkness (1992, France/United Kingdom/Germany), "Die Zusammenbruch der Sternenwlten wird sich -wie di Schöpfung- in grandioser Schönheit vollziehen" (The collapse of the stellar universe will occur -like creation- in grandiose splendour) (0:53:45), nor Thomas A Kempis ever said "It is only the pilgrims who in the travails of their earthly voyage do not lose their way whether our planet be frozen or scorched: they are guided by the same prayers, and suffering, and fervour, and woe" as it is stated at the beginning of Pilgrimage (2001, United Kingdom/Germany) (0:00:32) (Herzog \& Weigel 2010: 1; Cronin 2002: 295). Apart from quotes, whole scenes in his documentaries, too, have been sometimes staged. Again at the end of a film, in this case Echos aus einem düsteren Reich/Echoes from a sombre empire (1990, France/Germany), the journalist Michael Goldsmith is confronted with the heart-breaking view of a chimpanzee smoking a cigar and, unable to watch it, he asks Herzog, who stays behind camera, to stop filming the scene (1:30:14) Herzog's voice insists on the importance of filming the animal and he then accepts to stay, under the condition that it's the last scene of the film. The director accepts and the film ends. This dialogue is another idea by Herzog (Cronin 2002:242). In a scene 
of The White Diamond (2004, Germany/Japan/United Kingdom), the Guyana local Marc Anthony Yapp starts a memorable monologue about the jungle after having a walk through its thick vegetation (0:51:43). Herzog would later explain that both the monologue and his questions were scripted, and that the drop of water that led them to talk about the universe $(0: 52: 20)$ was in fact glycerine, with better optical qualities than water and more controllable (dvd commentary for The White Diamond). The line "I cannot hear what you say for the thunder that you are" pronounced by Yapp (0:52:39), too, comes from Cobra Verde. And of course, the people so aesthetically crawling on ice in Glocken aus der Tiefe: Glaube und Aberglaube in Rußland / Bells from the Deep: Faith and Superstition in Russia (1993, Germany/United States) (0:00:39) are not actual believers trying to listen to a mythic sunken city as we are told, but drunks that Herzog paid to play the role (Prager 2007: 131).

And it doesn't stop there; the dreams and visions that the subjects in Herzog's documentaries often experiment have been at least a few times recognised by the director as his creation. So is the case with in Julianes Sturz in den Dschungel/Wings of Hope (2000, Germany/United Kingdom). The film opens with altered yellowish images of Julianes walking the streets while the camera focuses on the strange, plastic faces of mannequins and Herzog's voice over narrates how in her dreams, Julianes walks normally but is interrupted by terrible faces $(0: 00: 18)$. Later, while recreating her journey through the jungle, Julianes herself tells the audience about two intervowen dreams she 
had shortly before awaking from the plane crash unconsciousness, with plenty of details about how she felt "sticky and caked in mud" (0:22:14). In the same style from the first dream, altered images appear later on the film showing Julianes getting lost among dead preserved animals. The directors' voice is again in charge of giving a meaning to what we see, speaking about how Julianes see the animals disappear into the abyss of time. $(0: 42: 38)$ The final narration of the film goes again on describing a dream, this time about an angel that will save Julianes (1:03:02). All of these tales are a product of the filmmaker's mind (Cronin 2002: 271), and we have to keep in mind that this is a short documentary of about 65 minutes, which make Herzog's inventions amount to half the total of the running time.

In the above mentioned Land des Schweigens und der Dunkelheit, where the life of the deaf blind Fini Straubinger is portrayed among others, a similar thing occurs: the film starts with a ski jump which we are prompt to believe is a recreation of a recurrent vision in Fini's imagination. Of course having in mind the short about Walter Steiner, we are able to unmask the true source of the scene, Herzog's imagination (Cronin 2002: 240). Likewise, the dream where Goldsmith is surrounded by a multitude of crabs pictured in Echos aus einem düsteren Reich is in the opinion of Brad Prager most likely an invention, too (2007: 196). 
There are also some inaccuracies on events sold as real, as exemplified by the affirmation present on Cave of Forgotten Dreams (2010, Canada/United States/France/Germany/United Kingdom) that the paintings on the wall of the Chauvet Cave are twice as old as any other cave painting in the world, or by the statement in Lektionen in Finsternis that "the city will soon be laid waste by war: now it is still alive, biding it's time" and "nobody has yet begun to suspect the impending doom" (0:02:28), when the footage was filmed with the Kuwait war already over. On top of including fictionalized parts in non-fiction films, there's the question of the veracity of the recall of historical facts carried on by Herzog in some of his feature films. One such example is his controversial depiction of the journey in search for El Dorado by the Spanish conquistador Lope de Aguirre and his men in Aguirre, der Zorn Gottes/Aguirre, the Wrath of God (1972, West Germany). As some historians have remarked (Pérez 2011; Becerra, 1997), there are many historical inaccuracies in the film the greatest of which is the use of the chronic by Gaspar de Carvajal, that were written not during Lope de Aguirre's expedition but during the one conducted by Gonzalo Pizarro and Francisco de Orellana more than fifteen years before. Similarly, both Cobra Verde (1987, West Germany/Ghana) and Queen of the Desert (2015, United States) include several geographic errors and anachronisms, when the rubber baron Carlos Fitzcarrald moved a ship over a piece of land it was way easier than in Herzog's account of it in Fitzcarraldo (1982, West Germany/Peru) and when the real Kaspar Hauser appeared in Nuremberg he was sixteen 
years old, which was obviously not the case in Jeder für sich und Gott gegen alle/The Enigma of Kaspar Hauser (1974, West Germany). Even the highly fictionalized Wo die grünen Ameisen träumen/Where the Green Ants Dream (1984, West Germany/Australia) earned him compliments such as "slanderous inaccuracies" for not being faithful to the authentic beliefs of the aborigines presented in the movie (Adams, 2011).

So far we have fiction in documentaries and historical mistakes in fictions based on reality to some extent. Herzog has also included "real" images in a feature film such Jeder für sich und Gott gegen alle: the domestic style scene from Kaspar's imaginations the Caucasus (1:11:39) is in fact footage from a trip by Herzog's brother (dvd commentary for Jeder für sich und Gott gegen alle). Other real elements included on a feature film are sometimes the same actors, as in the case of Invincible (2001, United Kingdom/Germany/Ireland/United States), where the actual strongman Jouko Ahola and the pianist Anna Gourari cover the main roles of a strongman and a pianist. And it gets more difficult than that. Films like Julianes Sturz in den Dschungel, Little Dieter Needs to Fly (1997, Germany/United Kingdom/France) and Echos aus einem düsteren Reich defy even more the frontier between reality and fiction by using the recreation of an event as their main narrative resource. When Dieter Dengler is explaining the story of how he survived in the jungle, showing us how to make fire and imitating his Vietnamese guards, do the audience perceive that as factual 
or as fictional? To which extent should we believe Julianes' tale if after watching his invented dreams we can no longer discern what is a story from what really happened? Moreover, Herzog has decided a couple of times to construct a fiction from a real fact from another film. The story about Walter Steiner having a speaking crow in Die große Ekstase des Bildschnitzers Steiner inspired a short feature film called Mit mir will niemand spielen/No One Will Play With Me (1976,

West Germany) where a boy only makes friends thanks to giving his speaking crow to a girl in his class. If we then think about Rescue Dawn (2006, United States/Luxembourg), a movie that reproduces all that Dieter Dengler told us having him played by Christian Bale, or about the fact that the footage used on Grizzly Man (2005, United States) was to some extent a fictionalized material as Timothy Threadwell himself staged it, the question whether what we see is fiction or not reaches absurdity - and probably nobody except Herzog can answer it considering he defiantly stated "anyway, acknowledge fake as fake contributes only to the triumph of accountants" (Herzog, 2010:1).

\section{The truth among the lies}

Identifying a certain part of a film as fiction or non-fiction says nothing about the nature of fiction in the work of the filmmaker, and stating that this mix is something common in his work doesn't 
succeed on explaining his artistic philosophy. For that, having reached this point, we have to turn to extra filmic material. And this is made easy by Herzog's like for public appearances and declarations, in which he always avoid any polemic that could emerge from his mix of reality and invention. He has explained, for example, how he doesn't see the use of a fake Pascal quote as a forgery, but as a mean of creating an experience of a "deeper inner truth", and then refers to how the Pietà/The Pity (Michelangelo Buonarroti, 1498-1499) portraits Jesus as a 33-year-old and her mother as if she was only seventeen (Herzog, 2010:9)

This deeper truth he has called "ecstatic truth". When asked for a definition of this often-cited concept, Herzog answers: "For me, a quest for truth is hard to articulate. It has very little to do with facts. Otherwise, the phone directory of Manhattan with four million entries would be the book of books -four million correct and truthful statements in the telephone directory. But it doesn't illuminate you at all. How do you approach such an elusive, strange thing as truth? I believe it is in poetry and music -you sense it immediately when you come across it." (Macnab, 2008: 20) Here, Herzog explicitly relates this truth with art, and identifies art as an opposite to facts. On another occasion he states: "The deep inner truth inherent in cinema can be discovered by not being bureaucratically, politically and mathematically correct. In other words, I start to invent and play with the 'facts' as we know them. Through invention, through imagination, through 
fabrication, I become more truthful than the little bureaucrats" (Cronin, 2002: 239) Now he goes

further by opposing the facts with "invention", "imagination", and "fabrication", a list of synonyms where we could easily add "fiction". To fictionalize, then, is not meant to prompt the imagination of someone (the audience), but to reflect the imagination of someone (the author), who is in charge of "discovering" the truth through fiction.

In this understanding of truth as something to be obtained by fiction Herzog gets close to the Romantic thoughts about truth. He has fought against being linked with German Romanticism in multiple occasions, blaming the label on the poor knowledge of German culture of those who call him so (Cronin 2002: 151). He only accepts the relation in one particular sense:

Geoffrey Macnab: You sometimes discuss an idea of ecstatic truth. Do you see yourself following in a German romantic tradition epitomised by, say, the 19th-century landscape painter Caspar David Friedrich?

Werner Herzog: No. Romantic culture has always been foreign to me something I really did not like that much. Of course, Caspar David Friedrich is the one who shows landscapes as if they were a quality of human beings. The jungle in Fitzcarraldo is a fever dream, as if it were a human quality. In that respect, I feel close to Caspar David Friedrich. But that is about the only connection I could construct between me and romantic culture. (Macnab, 2008)

Nonetheless, as Laurie Ruth Johnson observes in his study about this relation, "Herzog's rejection of cinema verité and his veneration of what he instead calls an "ecstasy of truth" recall the early 
romantics' intentionally fragmentary and ironic approach to artefacts, nature, and others." (Johnson, 2016:3). Fabrication and truth were deeply associated in the Romantic mind; defined by Rafael Argullol as one where the only cognitive conduct to access the truth is imagination (Argullol 1987:28). It is of common knowledge that the philosophy of the period had its best representative in the Romantic art; pages and pages of thought about an elusive truth wouldn't be as effective as a glance into Der Mönch am Meer/The Monk by the Sea (Caspar David Friedrich, 1808-1810), with the tiny figure immersed in a dense, ambiguous atmosphere and negating us its face. So, our question at this point is, has the idea of fiction as truth any aesthetic and thematic impact in the contents of Werner Herzog's films?

We can answer that by turning to Jeder für sich und Gott gegen alle. Kaspar Hauser spends his whole life in a cave, alone and in the dark. As Simonetta Salvestroni notes, Kaspar lives in a very similar condition to the deaf blind in Land des Schweigens und der Dunkelheit (Salvestroni 2013: 49). Like in Plato's cave, he has his hands chained to the ground. The shadows that the habitants of Plato's story see projected as a result of the objects that someone moves in front of the fire find their equivalent in the mysterious visits that teach him to write his name and feed him, being this all his contact with the human world. But this is the reversal of a myth: the outside light of the sun and the rational knowledge will do nothing but end with Kaspar's life, only temporarily enjoyed 
when invoking the dreams and visions he embraced in his closure. The darkness to which the young man is subject in the first years of his life is not ignorance, as Montserrat Rossés points out: "Kaspar has the advantage of hearing the silence and dreaming dreams, a romantic poet for whom the world outside the cave will be more cruel and inhospitable than his dark refuge. Darkness is the beginning of creation and the beginning of Kaspar. Darkness is also a value of romanticism" (Rossés 1991: 47). The interior of the cavern is in this herzogian universe the true path to follow, involving the use the irrational imagination (eikasia) that Plato took as wrong. Entering it will mean to look through inner vision, through fiction; the ultimate truth does not reside in the intellectual understanding of the world, but in one that goes through the imagination, as opposite as society as pictured in the movie believes -"You're just coming along, Kaspar, you used to believe your dreams were true" says his instructor (1:11:15).

All of Herzog's thought about fiction is contained within this visual and narrative metaphor. For Plato the cave was fiction, merely a deformation of the world. For Herzog the real cave, the one that would be good to escape, is that of factual knowledge. The cave, as we've seen, is a good motif to illustrate the existence of a truth that goes beyond facts, and that's because it touches both features that Herzog gives it. A cave is both "inner" and "deep", a cave has to be excavated in order to be found, just like truth. In fact, the cinema of Herzog has been compared to archaeology (Pintor 2007), and he himself, being at the top of the Tokyo Tower on conversation with Wim 
Wenders for his film Tokyo Ga (1985, United States/West Germany), remarked: "We'd have to dig like an archaeologist, to dig down... before we could find anything pure in this decaying landscape. [...] We need pure and absolute images that reflect our civilization as whole and our own deep inner voices". Again we have depth and excavation, again the image of a truth buried among facts for which we have to pass surface.

\section{Motifs of fiction}

The cave motif is largely explored again by Herzog in The Cave of Forgotten Dreams. This time Herzog dedicates a whole movie to the exploration of the Chauvet Cave in Southern France, where the oldest human paintings were discovered. In this film Herzog's intention seems to be to reanimate this particular space. When we are shown the imprints of a wolf and a child penetrating together into the cave, Herzog's voiceover suggests: "Did the wolf stalk the boy? Did they walk together as friends? Or were they separated by thousands of years?". Again, the cave is presented as the place for fiction: the focus of the movie is on the stories behind it. The authors of the paintings are treated by the voiceover as "artists" and the animals depicted are accompanied by the narration of possible events involving them, all of this submerged in a dark atmosphere lightened only by the crew's lanterns, what seems to benefit this feeling of tale. As explained in the movie, 
the cavemen could have painted more easily the walls at the entrance of the cave, which at times was illuminated by sunlight. But they chose to do it in the darkest corners of the cavern. Darkness negates observation, what rational knowledge is based upon: darkness wipes out external vision and imposes a new one implying imagination. It is of Gilles Deleuze's opinion that while the light of day exposes a unique reality, the shadow of the night allows imagining different states of the soul (Deleuze 2014:130).

To be in the dark, a word "thematically very important in Romanticism" (Frye 2005:114), too, is to be unreachable by others. Just as the truth covers itself in veils, the characters in Herzog's films cover themselves from civilisation. In the director's own words: "My characters have no shadows. They come out of the darkness, and such people have no shadows. The light hurts them. They are there, and then gone, to their obscurity" (quoted in Bachman, 1977:7). Probably the most literal illustration for this quote is the vampire played by Klaus Kinski in Nosferatu: Phantom der Nacht / Nosferatu the Vampire (1979, West Germany/France). Nosferatu, along with his castle, makes his appearances solely at night. It is not only that he's a vampire: he's a tale. The gipsies that give refuge to Jonathan, the main character, and whom he asks for indications, tell him so: they advise him not to proceed with his journey to the castle because it doesn't exist; it exists only in the mind of men $(0: 17: 20)$. 
Darkness is to images what silence is to words - Françoise Meltzer has talked about the frequency in which Romantic literature used words such as "indescribable", "inexplicable", "unspeakable" (Meltzer 2013). The truth of Romantics started where language ended, and to use words to express inexpression was to explore its limits. Likewise, the truth of Herzog starts where vision ends. Rudolf Otto also made this comparison: "In neither the sublime nor the magical, effective as they are, has art more than an indirect means of representing the numinous. Of directer methods our Western art has only two, and they are in a noteworthy way negative, viz. darkness and silence" (Otto 1958: 95). What Herzog is chasing may not be numinous, but it shares the same sense of something deeper, more transcendental than plain reality. Fiction becomes the tool to evoke the unfilmable.

In The White Diamond a professional climber is sent with a camera to film an inaccessible cave.

Herzog's voiceover narrates it this way:

From the bottom of the falls the gigantic cave isn't accessible and has resisted all attempts by explorers. We lower the camera to him, hoping to gaze into the unknown. Later we decided not to show its footage. We will show only the image from the spinning camera as we pulled it back up on a rope. $(0: 34: 12)$ 
The decision to keep the footage of the cave unseen is a very good equivalent to say "indescribable". After this scene there's an interesting dialog between the ex leader of an Amerindian tribe and Herzog:

Anthony Melville: If I had wings, one important thing, I would like to know what's behind there. [...] Nobody knows what's behind, what lies, what story, what really is behind there. If I had dreams, one of my first dreams is to go there to see what's there. We have stories like the legend that goes that behind there are huge big snakes living there that protect certain treasures, like diamond gold whatever. I mean that's a legend that says that.

Werner Herzog: One of our climbers went down on a rope and look into it. With a camera. He saw what's in there.

Anthony Melville: I don't think you should ever publish it. I mean what you see is yours. I mean you keep it to yourself. But I don't think it should be published all world [...] It would be lost, the whole essence about our culture, would die away, we'd loose it. (0:36:15)

After this, Herzog starts narrating the story behind the name of the falls covering the cave. For both of them, then, if the cave contains something that is legend. In this case, Herzog already has the fictions from the cave, he doesn't need to enter it, to shed light to its darkness: why show reality when we have this "essence" Melville names? Why see when we can imagine?

Caspar David Friedrich painted inside of a room. There he closed his physical eyes and opened his spiritual ones (Honour, 1996:66). Similarly, Herzog gives a vision to Fini Straubinger, who cannot use his actual eyes. Let's take a look at the beginning of Land des Schweigens und der Dunkelheit. 
First comes the darkness. Then, from the black, a vague landscape appears to be lost again in the dark. Suddenly a skier jumps, flies in full colour. Again, darkness. Fini narrates what she "sees": a path covered in clouds. It's beautiful, she says. Later in this same film, she will clarify that being blind doesn't mean living in absolute black but in colours. Of course, these images don't come from her eyes - they are imaginations. Imaginations that emerge from blackness - wouldn't this be a nice definition for the nature of film? Herzog has a deep insistence on these altered states of vision, where we could include darkness, a translation for his absence of faith in the factual reality, for his distrust on it. If Fini, being blind, will be able to see a ski jumper, the Dieter Dengler in Rescue Dawn will be able to see his friend although he has been killed, and Hias of Herz aus Glas/Heart of Glass (1976, West Germany) has visions about the future of his village -the fact that some of the actors were hypnotized as told by Herzog contributes, too, to the emphasis on altered vision. There are the already mentioned dreams of Julianes Sturz in den Dschungel and the ones in Invincible and Nosferatu: Phantom der Nacht; The White Diamond starts by defining flying as an "age old dream" (0:00:37); both Cave of Forgotten Dreams and Wo die grünen Ameisen träumen make dreams their central metaphor. In Lo and Behold: Reveries of the Connected World (2016, United States) Herzog still asks the question "Could it be that the Internet dream of itself?"(1:12:07). These dreams and visions are always more like a reverie, a daydream, something 
that comes from the unconscious but that has this poetic feeling which makes us perceive it almost like a short fiction inside the fiction, and let me exemplify this with a scene from Cerro Torre: Schrei aus Stein / Scream of Stone (1991, Germany/France/Canada/Italy/Argentina). One of the main characters, just before confronting himself with the callenge of climbing the Cerro Torre peak, tells his girlfriend:

I've had a dream. It was a strange dream. A train raced through the land and penetrated a mountain range. It's wheels were glowing. Then suddenly one car burst into flames and the train stopped. Men tried to put out the flames but they couldn't. So they decided to send the train on by itself, just to get it away. And I saw this empty burning train race away. I don't know where. (0:15:27).

At a metaphorical level this could be related to the fears of the climber, but Herzog makes the tale stand out by accompanying it with images of mountains getting lost in a dense fog. The meaning of the dream, just like the mountains, is covered. Dreams are another layer of fiction, thus a deeper layer of truth, more difficult to chase.

Albert Elduque beautifully says about the landscape dreams in Jeder für sich und Gott gegen Alle that they have a "notable flicker that makes them nascent and moribund, always appearing and always about to escape, fully evanescent" (Elduque, 2013:2). Some images in Herzog seem to run away from us. Sometimes they hide. Romanticism hid Nature under fogs and clouds $-\mathrm{a}$ veil that 
only imagination could trespass (Argullol 1987: 110). Herzog uses all kinds of veils to cover the events of their stories. Herz aus Glas begins with Hias pointing out to a curtain of fog, and we never know what's behind it. In Encounters at the End of the World the scientists try find themselves among a storm of snow, and Lektionen in Finsternis is partially covered by the black smoke of oil, having begun with the sentence "A planet in our Solar System. White mountain ranges. Clouds. A land shrouded in mist." (0:00:49) And we can not forget the jungle, for Herzog always dense, a density that makes the explorations by Aguirre and Fitzcarraldo almost impossible, that resists enlightenment. It's frequent that Herzog shows us the jungle from an aerial point of view that makes of it just a huge green mass to then penetrate it, such is the case in The White Diamond. Nature becomes not a mere background, but a thickness through which we have to enter to find truth. Or, at least, fiction: just like the drunks freezing their ears to listen to the sounds of a mythical city. "We'd have to dig like an archaeologist, to dig down...".

\section{Conclusions}

Werner Herzog is known for going to the most unreachable corners of the world in order to create his films -he has already been in all continents, and has even joked about wanting to go to space.

His stories, both based in real facts and not, are not to be found in every day reality; they have to 
come out of a strong search. This concept of his work has a double reflection on his films, as this paper has argued. On one hand, being the process of creation so important for him, reality leaks into fiction and vice versa. We have identified some of his inventions and inaccuracies to then proceed to another type of analysis: his idea that factual truth is surpassed by a poetic one is expressed throughout his movies aesthetically and narratively. Motifs of depth, darkness, thickness, dreams and visions appear as the best explanation for what fiction means for Werner Herzog: an inner and deeper truth.

\section{References}

Adams, Phillip. 2011. "The Wrath of Herzog” The Australian.

https://www.theaustralian.com.au/life/columnists/the-wrath-of-herzog/newsstory/b7abbb95af8fc77c79bcea10fea9c97f

Argullol, Rafael. 1987. La atracción del abismo: un itinerario por el paisaje romántico. Barcelona.

Bachmann, Gideon. 1977. "The man on the volcano: a portrait of Werner Herzog" Film Quarterly. 31 (1): 2-10.

Balló, Jordi. 2000. Imatges del silenci: els motius visuals en el cinema. Barcelona.

Balló, Jordi and Alain Bergala (eds.). 2016. Motivos visuales del cine. Barcelona. 
Becerra, Carmen. 1997. "La figura mítica de Lope de Aguirre en las versiones de W. Herzog y

C. Saura" Hispanistica XX, 15: 331-340.

https://dialnet.unirioja.es/servlet/articulo?codigo=3609206

Casau, Gerard. 2014. "El gran éxtasis del escultor Steiner”. Dirigido por, 440: 74-75.

Corrigan, Timothy. 2013. The Films of Werner Herzog: Between Mirage and History. New York and London.

Cronin, Paul. 2002. Herzog on Herzog. London.

Deleuze, Gilles. 2014. La imagen-movimiento. Barcelona.

Elduque, Albert. 2013. "Los relieves del tiempo. La cueva de los sueños olvidados (Cave of forgotten dreams, Werner Herzog, 2011)" Filmhistoria 23 (2): 1-5.

https://dialnet.unirioja.es/servlet/articulo?codigo $=5368389$

Frye, Northrop. 2005. Northrop Frye's Writings on the Eighteenth and Nineteenth Centuries, vo.17. Toronto.

Herzog, Werner and Moira Weigel. 2010. "On the Absolute, the Sublime and the Ecstatic Truth" Arion: A Journal of Humanities and the Classics, Third Series, 17 (3):1-12. http://www.jstor.org/stable/40645998

Honour, Hugh. 1996. El Romanticismo. Salamanca. 
Macnab, Geoffrey. 2008. "Wild white yonder" Sight \& Sound, 18 (6): 20-22.

Johnson, Laurie Ruth. 2016. Forgotten Dreams: Revisiting Romanticism in the Cinema of

Werner Herzog. Rochester.

Meltzer, Françoise. 2003. In Search of Nostalgia: Ruins. University of Chicago Humanities Day Keynote Address.

Otto, Rudolf. 1958. The idea of the Holy. Oxford.

Pérez Murillo, María Dolores. 2011. "Dos visiones de Lope de Aguirre a través del cine europeo:

Werner Herzog y Carlos Saura” Trocadero, 23: 261-275.

http://dx.doi.org/10.25267/Trocadero.2011.i23.14

Pintor, Ivan. 2007. “En los límites del vagabundo. Pervivencia del Nuevo Cine Alemán: Wim

Wenders, Werner Herzog, Volker Schlöndorff' In Paisajes y figuras: perplejos. El Nuevo Cine Alemán (1962-1982), edited by J. E. Monterde and C. Losilla, 155-176. Valencia.

Prager, Brad. 2007. The cinema of Werner Herzog: Aesthetic Ecstasy and Truth. London.

Rossés, Montserrat. 1997. Nuevo cine alemán. Madrid.

Salvestroni, Simonetta. 2013. Il Cinema di Werner Herzog e la Germania. Kaspar Hauser, Herz aus Glas, Nosferatu, Woyzeck, Invincibile. Bologne.

Walton, Kendall. 1990. Mimesis as Make-Believe: On the Foundations of the Representational Arts. Cambridge. 
Weinrichter, Antonio. 2007. Caminar sobre hielo y fuego. Los documentales de Werner Herzog. Madrid.

\section{Filmography}

Herzog, Werner. 1971. Land des Schweigens und der Dunkelheit. Referat für Filmgeschichte;

Werner Herzog Filmproduktion.

Herzog, Werner. 1972. Aguirre, der Zorn Gottes/Aguirre, the Wrath of God. Werner Herzog Filmproduktion; Hessischer Rundfunk.

Herzog, Werner. 1974. Die große Ekstase des Bildschnitzers Steiner. Süddeutscher Rundfunk; Werner Herzog Filmproduktion,

Herzog, Werner. 1974. Jeder für sich und Gott gegen alle. Filmverlag der Autoren; Werner Herzog Filmproduktion; Zweites Deutsches Fernsehen.

Herzog, Werner. 1976. Mit mir will niemand spielen. Werner Herzog Filmproduktion.

Herzog, Werner. 1976. Herz aus Glas/Heart of Glass. Werner Herzog Filmproduktion.

Herzog, Werner. 1979. Nosferatu: Phantom der Nacht / Nosferatu the Vampire. Werner Herzog Filmproduktion; Gaumont; Zweites Deutsches Fernsehen. 
Herzog, Werner. 1982. Fitzcarraldo. Werner Herzog Filmproduktion; Pro-ject Filmproduktion;

Filmverlag der Autoren.

Herzog, Werner. 1984. Wo die grünen Ameisen träumen. Pro-ject Filmproduktion; Werner

Herzog Filmproduktion; Zweites Deutsches Fernsehen.

Herzog, Werner. 1987. Cobra Verde. Werner Herzog Filmproduktion; Zweites Deutsches

Fernsehen; Ghana Film Industry Corporation.

Herzog, Werner. 1990. Echos aus einem düsteren Reich. Films sans frontières; Sera

Filmproduktion; Werner Herzog Filmproduktion.

Herzog, Werner. 1991. Cerro Torre: Schrei aus Stein. Sera Filmproduktion; Molécule; Films

A2; Les Films Stock International; Wildlife Films; Neue Constantin Film; Zweites

Deutsches Fernsehen (ZDF); Canal +; Téléfilm Canada; Lucky Red; Rai 2; European

Script Fund; MEDIA Programme of the European Union.

Herzog, Werner. 1992. Lektionen in Finsternis. Canal +; Première; Werner Herzog

Filmproduktion.

Herzog, Werner. 1993. Glocken aus der Tiefe: Glaube und Aberglaube in Rußland. Werner

Herzog Filmproduktion; Momentous Events.

Herzog, Werner. 1997. Little Dieter Needs to Fly. Werner Herzog Filmproduktion; Zweites

Deutsches Fernsehen; British Broadcasting Corporation; Arte.

CINEJ Cinema Journal: Inner and deeper: Motifs of fiction in Werner Herzog's films 
Herzog, Werner. 2000. Julianes Sturz in den Dschungel. Werner Herzog Filmproduktion; British Broadcasting Corporation.

Herzog, Werner. 2001. Invincible. Werner Herzog Filmproduktion; Tatfilm; Little Bird.

Herzog, Werner. 2001. Pilgrimage. Pipeline Films.

Herzog, Werner. 2004. The White Diamond. Marco Polo Film AG; NDR Naturfilm.

Herzog, Werner. 2005. Grizzly Man. Discovery Docs; Real Big Production.

Herzog, Werner. 2006. Rescue Dawn. Metro-Goldwyn-Mayer; Top Gun Productions; Thema Production; Gibraltar Films.

Herzog, Werner. 2010. Cave of Forgotten Dreams. Creative Differences; History Films; Ministère de la Culture et de la Communication; Arte France; Werner Herzog Filmproduktion.

Herzog, Werner. 2015. Queen of the Desert. Benaroya Pictures; H Films; Raslan Company of America.

Herzog, Werner. 2016. Lo and Behold: Reveries of the Connected World. Saville Productions. Wenders, Wim. 1985. Tokyo Ga. Chris Sievernich Filmproduktion; Gray City; Westdeutscher Rundfunk. 